\title{
Water Out of Fire: Novel Women, National Fictions and the Legacy of Nehruvian Developmentalism in India
}

\author{
DEVLEENA GHOSH
}

\begin{abstract}
In the post-independence period in India, popular fictions present a paradox: they represent the corruption of the era as well as the desirability of its modernity. In the work of overwhelmingly successful writers such as Shankar, the path of Nehruvian development is a double sign. It represents the corruption of the 'licence raj' as well as the desirable lifestyle and possessions of the educated elite. The more the nation modernises, the more corrupt and desirable it becomes. All the noble social goals of the Nehru era, education, women's emancipation, progress become transactional - things to be exchanged for wealth, western technology and status. There is no room for integrity here; integrity is possible either in the past or in the West. These fictions tell the story of the 'deferral' of Western modernity in the imaginary of the postcolonial nation. Women, in these fictions, are especially ambiguous; though modernised and educated, they also retain their traditional roles and conventional gender relationships are valorised. This flawed representation of the modern nation also embodies its tragedy. This article concludes that the failure of the post-independence Nehruvian development project and its noble social goals has created a space that allows economic liberalisation and religious fundamentalism to flourish.
\end{abstract}

After almost fifty years of self-rule, the old certitudes of Indian politics have crumbled. It is now recognised that democracy in India was not a bequest from the British; rather it was established after a profound historical rupture as a consequence of which Indians were unable to find sufficient resources in their own past to construct their future. This has meant bringing new ways of imagining the Indian nation into play. ${ }^{i}$ Popular fiction has occupied an important position in this process. In post-1947 India, popular fictions have presented a paradox: they represent the corruption of the era as well as the desirability of its modernity. Women, in these fictions, are especially ambiguous; though modernised and educated, they retain their traditional roles and conventional gender relationships are valorised. This vision of the nation represents the tragedy and failure of the earlier efforts to establish India as a modern nation. More broadly, this article argues that the demise of the state-guided Nehruvian development project in independent India and its inability to meet the noble social goals propounded by the country's first prime minister (Jawaharlal Nehru 1947-1964) created a space that has subsequently allowed economic liberalisation and religious fundamentalism to flourish. 


\section{Nehruvian Developmentalism}

While the nationalist leadership established independent India on the basis of colonial institutions, the socialist leanings of Jawaharlal Nehru who dominated the country's politics in the 1950s and early 1960s, profoundly influenced the new nation-state's economic and political trajectory both during his lifetime and long after his death in 1964. In the context of the emerging Cold War, Nehru attempted to direct national development in India between the capitalism, of the First World, and the communism of the Soviet Bloc. Nehru's tenure in office is crucial because, during this time, the state stabilised and became a developmental agency that aspired to penetrate all areas of Indian society. In the 1950s, the vision of development articulated by the Indian government, led by Nehru and the Congress Party (the organizational successor to the Indian National Congress), was not only socialist and nationalist but also technocratic and paternalistic. Sunil Khilnani, for example, claims that Nehru believed that only a national state, centrally responsible for directing economic development, could safeguard India's future progress and independence. Concurrently, this state also had to build a constitutional, non-religious regime, extend social opportunities, and maintain sovereignty in the international arena. Nehru was convinced by the history of the West that an independent India could simultaneously industrialise, maintain constitutional democracy and direct economic and social redistribution. In some ways, says Khilnani, this project was closer to post-war European social democracy than Soviet practice. Nehru proposed a view of the state's domestic responsibilities that had parallels with Keynesian ideas in that the state had actively to create conditions for economic expansion by investment in and direction of a public sector that would function alongside private enterprise in a mixed economy, acting as a counterweight to the cyclical swings of private investment. ${ }^{\text {ii }}$

By the mid-1960s, however, it became clear that the beneficiaries of national development were the private commercial and industrial groups and bureaucratic and professional elites directly or indirectly connected to the political leadership rather than the majority of the population. ${ }^{\text {iii }}$ Under the stewardship of Nehru's successor, Lal Bahadur Shastri, the overall approach to national development altered significantly. Private investment in industry was encouraged as were incentives rather than controls in development planning. There were also massive public investments in capital-intensive rural projects, such as the 'Green Revolution' in the Punjab. By the time of Shastri’s death in January 1966, the key elements of Nehru's 
conception of national development (an emphasis on public sector heavy industries and land reform and the cooperative reorganisation of agriculture), had been almost completely marginalised. ${ }^{\text {iv }}$

Nehru's daughter, Indira Gandhi, whose populist politics redirected the program of national development away from the Nehruvian vision centred on industrialization to the idea of India as a modernising, but basically agricultural nation, succeeded Shastri. Gandhi was however unable to maintain her populist developmentalism and by the mid-1970s, there was a growing gulf between her socialist rhetoric and increasing levels of inequality and immiseration, particularly in rural areas. The failure of Mrs Gandhi's party to deliver to rural areas is demonstrated by the parliamentary success of communist parties and several important communist-led rural insurgencies in the 1960s and early 1970s. ${ }^{\mathrm{v}}$ The failure of Mrs Gandhi's version of the national development project was directly connected to the increasingly capital-intensive character of farming which broke down the 'semi-feudal ties' that had often connected rich peasants to their poor and landless agricultural workers. This, along with an increasingly unequal distribution of wealth exacerbated social tensions in the countryside. In the 1980s successive governments, under Mrs. Gandhi (from 1979) and her son Rajiv Gandhi (from 1984) dismantled many of the institutions of state-guided national development in India. $^{\text {vi }}$

The post-colonial state in India was relatively unique among the new states of Asia and Africa in setting itself huge developmental targets to be achieved by democratic means. For most of the fifty odd years since independence, the electoral dominance of the Congress Party and the availability of a sophisticated and extensive public bureaucracy gave the Indian economy a remarkable continuity of direction. Unlike China under Mao Zedong (1949-1976), India did not eschew democracy to make a revolutionary leap into industrialisation nor did its leadership and intelligentsia intentionally veer to the market as China's post-Mao leadership did. In fact, in 1991, when the end of the Cold War increased the pressure on India's still highly regulated national economy, the Indian state was pushed towards liberalisation and market-oriented economic reform by expatriate intellectuals and economists employed by international economic agencies and universities. Economists such as Jagdish Bhagwati held that India's economy had failed because of 'disappointing productivity performance' and a distrust of the market combined with faith in central control. This nurtured misconceived economic policies which continued to keep the concentration of economic power out of private hands. The 
liberalisers argued that India must create conditions for growth since this was necessary for the alleviation of poverty. But still centrally at issue in the debate about economic reform was the idea of India, about the kind of society liberalisation would create ${ }^{\mathrm{vii}}$. The 1980s saw the rise of Hindu nationalism in India and the eventual (albeit unstable) formation of a government by the anti-secular nationalist Bharatiya Janata Party (BJP) by the late 1990s. While the dynamics of this shift are complicated, the growth of Hindu nationalism is a reaction, in part, to the failure of the state-guided national development project of the post-1947 era. ${ }^{\text {viii }}$

Colonial economic policies in India resulted in a comparatively weak and unstable bourgeoisie that, nevertheless, exercises a leadership function in coalition with rich farmers, the bureaucracy and the urban professional middle classes. ${ }^{\text {ix }}$ However, for a thoroughgoing bourgeois revolution to be effected and for industrialisation to take place, a domestic market must be built up by reducing poverty in the countryside. Since land reforms have been largely ineffective because of the influence of the landed interests in the coalition of ruling classes, the entire planning process has been an exercise in trying to promote industrialisation without radical agricultural transformation. ${ }^{\mathrm{x}}$ The theory behind the first three decades of planning was that redistribution of incomes and property was necessary to create a market for goods and services. Since 1980, however, the rationale has been that development can be achieved even in a limited market if purchasing power is enhanced for a small elite in services, trade and manufacturing. This can be done by raising their emoluments, giving them tax exemptions and reductions and using public money to provide loans and subsidized interest rates in order to create a market for luxury goods. However, the incentives for the private sector, and the slashing of government expenditure, which necessarily follow liberalization and structural adjustment affect the poor, especially poor women and children, adversely. The conflict between the rhetoric of liberalisation, the reality of immiseration and the discourses of national development have opened up a space which the forces of Hindu fundamentalism have found easy to occupy. The fictions discussed in the rest of this essay describe some of these processes.

\section{Women and Nationalism}


In this trajectory of ideas, from redistributive developmental practices to liberalisation, where do women stand in the imaginary of the nation? In her introduction to the book Feminist Nationalism, Lois West presents the dilemma of women and nationalism by asking: "How could women be nationalists when they did not have equal rights? How could women not be nationalists when they loved their country, people and home? ${ }^{\mathrm{xi}}$, She points out that women are constituted as citizens differently from men; for example, in access to paternal property rights (Hindu women in India) or equal rights under the constitution (in the USA) to name only two. Nira Yuval-Davis and Floya Anthias identify women as active transmitters and producers of national culture. They point out that nationalism was constituted from the very beginning as a gendered discourse. ${ }^{\text {xii }}$ However, as Sylvia Walby emphasises, the literature on women and nation "has engaged but little with the differential integration of women and men into the national project.”xiii

According to Geraldine Heng, national liberation movements are also inadvertently the record of a triumphant nationalism that makes its gains at the expense of women. Nationalist movements made common cause with women's issues because nationalism requires a certain self-representational vocabulary - a definitional apparatus to imagine and describe itself. ${ }^{\text {xiv }}$ Partha Chatterjee, in writing about the social construction of Indian nationalism historically, has demonstrated how patriarchal nationalism was disseminated through colonialism and how struggles over views of nationalism are inherently gendered. Even where anticolonial nationalism was defined as oppositional to Western colonialism, women were limited to the contexts of the family, although the centrality of family relations was reinterpreted and emphasized. The discourse over nationalism in India situated “the women's question' in an inner domain of sovereignty, far removed from the arena of political contest with the colonial state. ${ }^{\mathrm{xv}}$ Particular social practices degrading to Indian women were used by colonialists as examples of the 'unworthiness' of Indian customs and traditions, which necessitated embracing the 'modernisation' of colonialism. Indian (male) nationalists reacted to this by situating women in the spiritual realm of the home, which was superior to the material realm of the world being constructed and represented by colonial interests.

The relevance of Chatterjee's account to modern India is that the construction of nationalism is still a gendered dynamic in the arena of the family. This is an extract from an article published in a popular annual three years after India's independence. It was titled 'Santan Janani-Jatir Janani' ${ }^{\text {xvi }}$ : 
Women are the creators of the nation. The community is created by human beings but each of these humans was once nurtured in the lap of a mother, hence who else can be the maker of the nation than women? This is certain that human resources are more valuable than wealth and the creator has left the development of this human wealth in the hands of women.

The writer continues by quoting from Swami Vivekananda:

The ideal of an Indian woman is that marvellous selflessness of motherhood, the all-enduring, all forgiving mother...In Hindu thought being a mother is the ultimate aim of every woman.

She concludes with the English proverb "The hand that rocks the cradle rules the world" in proof of her thesis. ${ }^{\text {xvii }}$

Nations, therefore, are frequently figured through the iconography of familial and domestic space. Within this space, women are represented as the atavistic and authentic body of national tradition and men by contrast represent the progressive agent of national modernity embodying nationalism's progressive or revolutionary principle of discontinuity. ${ }^{\text {xviii }}$ In postcolonial India, the cultural and gendered politics of Indian nationalism can be read through the texts of popular novels where constructions of the 'modern' women in the service of the Nehruvian national development project and its successors are presented for the consumption of the literate middle class. (I have confined my discussion primarily to the fiction published in Bengali after 1947 by one overwhelmingly successful author, Shankar). 


\section{The Rhetoric of Modernity}

Shankar is a phenomenon in the Bengali publishing industry whose novels have found a resonance in the Bengali psyche that sits paradoxically with the overt left political ambience of Bengali society. His work has created new directions in the Bengali novel by demonstrating the ways in which the rhetoric of development, modernisation and individualism permeated the discourse of Bengali society in this period. A readership survey in Eastern India in 1981 and later in 1992 found that readers of Shankar's novels scored the highest in all categories of income and age distribution for weekly magazines. Women were by far the largest consumers of these novels and Shankar was nominated by $82 \%$ of those surveyed as their favourite writer $^{\text {xix }}$. A clear stereotype also emerged from this survey about readers' perceptions of themselves. They were overwhelmingly Hindu and categorised themselves as married, middle-class, cheerful, cine-goers, moderate to highly educated and traditional and 'stay at home'. They defined their preferences as intellectually oriented, for example towards comparatively highbrow and political films and intellectual rather than popular novels. The analysis commented:

These readers seem to be 'progressive/modern/intellectual' in outlook though not in their lifestyle. Perhaps this image is dear to them. ${ }^{\mathrm{xx}}$

Shankar's popularity reaches outside Bengal as well. His work has been translated into the major Indian languages and the renowned director Satyajit Ray has filmed two of his novels.

The family, according to Anne McClintock, offered national narratives an indispensable metaphoric figure for sanctioning national hierarchy within a putative organic unity of interests. ${ }^{x x i}$ In Shankar's work, these 'natural' hierarchies are strengthened; the nurturing female and the work-oriented male usually represents normal relationships of family life. The therapeutic functions of these novels lie in their reconstruction of the average citizen as centrally important in the context of the institutions of modern life which, s/he fears, really dwarf him/her. Gestures towards social criticism are thus usefully absorbed without dismantling old hierarchies or radically upsetting the status quo. In the traditional symbolism of this kind of fiction, the radical is tamed and the conservative liberalised; one of the useful social functions that it performs is to make collective anxieties manageable by embedding them in 
comfortably familiar stereotypes, a common mode of evasion of social problems by a radical simplification of the complex into manageable symbolic units.

The society depicted in this fiction is primarily nationalist, Hindu and middle-class. A favourite backdrop is the Indian corporate world of the 1960's, '70's and '80's, harnessed in the cause of the development of the nation but notorious for its tolerance, indeed encouragement of institutionalised corruption. This licence 'raj' was established by Nehruvian policies of development. In this regime, licenses to establish factories, produce goods or run commercial farms were sold by a huge, inefficient and corrupt government bureaucracy which openly courted bribes and 'gifts'. There is also a generational conflict present in this fiction presaging an apprehension of living in the young nation. Young lower middle-class men, especially, engender a deep uneasiness; they represent the uncontrollable potency of masculine energy whose desires are thwarted by the new polity. In a famous novel which was also turned into a film by Satyajit Ray, a father muses uneasily about his unemployed son whom he feels is " out of tune in the picture post-card scene of [their] happy family life”. Young men, he thinks, have "turned their homes into jungles".xxii

In these texts, the old order is ritually challenged by tomorrow's headlines and the discourses of modernity before being re-valorised. Part of the success of Shankar's writing appears to be that it creates the illusion of questioning by purporting to challenge convention and the established order while tensions in social or gender matters are usually introduced as props to validate location and class. The props reassure the reader that the novel is not really ignoring social issues or putting important matters out of mind but the consequence usually is to reduce such matters to so much local colour and authentication. Complex social and economic technicalities are converted to comfortably primitive formulations of human motivations.

\section{Technology, Commodity and Desire}

The predominant language of the texts is that of upward mobility that the citizens of the new nation consider a most desirable attribute. Women are guardians of a system of values produced by the acquisition of appropriate commodities. Sections of these novels resemble self-help manuals that give the predominantly female readers a glimpse of high society 
etiquette and mores. Thus if the boss comes to dinner, the hostess must dress particularly carefully because her appearance and clothing signify her place in the social and company hierarchy. She must not look too dressed-up, or too casual; she must also give the impression that she has personally supervised the dinner preparations. Her make-up must be toned down and the sari should have the simplicity of expensive haute couture. ${ }^{\text {xxiii }}$

In this new era, the middle-classes know that they are not judged by their qualities but by their objects - the private relationships hide a profound recognition and acceptance of the public verdict. Yet their progress on the social scale is relative and lacks legitimacy because their acquired situation can never have an intrinsic value. It is this thwarted legitimacy (with respect to cultural, political and professional life) which makes the middle-class invest in the private universe, in private property and the accumulation of objects with a dedication that masks the fact that true social recognition has escaped them. ${ }^{\text {xxiv }}$ Thus, it is the wife of a senior officer in a foreign owned company who insists that he should take a flask to office as befits his position. She demonstrates to her husband the office hierarchies even in such a seemingly simple action such as drinking water:

Shyamalendu examined the situation carefully and realised that one's position in the office could be deduced from one's arrangements for drinking water. He did not know how the people in the lowest positions - i.e. the bearers drank water. In all these years of service he had never actually seen a bearer drink water. He had heard that a glass or two were hidden behind the filing cabinets and used by whoever required them. Then the babus. Each of them had on their tables a glass with a number in red on the bottom. ... The glasses of the senior clerks were larger than those of the junior babus. Then came the local ... [or] Indian assistants. Their glasses were not so large but fine and etched with beautiful flowers and accompanied by two colourful enamelled lids. Above them were the junior officers. They had red containers on their tables for their glasses and had to remove the concave lid to drink water. The covers used by the senior officers had fine needlepoint on them. But for the managers, office water was completely unpalatable. They had to have flasks. And the directors had two flasks. One contained cold water and only God knew what was in the other. $^{\text {xxv }}$ 
The constitution of the upwardly mobile self as social subject depends on the acquisition of appropriate objects to project the desired image via the nuances of codes in dress and possessions. The consumer citizens put on their identities at the same time as their clothes. Their possessions must have pedigrees that guarantee them as successful citizens of the new nation.

The novels also show a fascination with new technology and gadgetry that is intrinsically linked to the trope of development. Alien configurations are digested and reduced to familiarity for the easier consumption of the readers. The value of time, the novel idea of counting calories, these buzz-words of modernity are thus domesticated and put into circulation. For example, Shankar might describe his protagonist's watch over forty pages, in close, almost loving, detail:

Time is most valuable in business and industry so I use the best watch in the world, so that not even one second is wasted. With the best Swiss watch on my wrist, I am ready to use profitably every minute of every day, but the sisters and brothers of my motherland are indifferent to time... My quartz watch is a special computer. It can tell me when I have exercised away my extra calories ...The quartz watch reminds me that it is time for my medicine. All the various chores of my day are programmed into my watch - this mechanical wife reminds me dutifully of them.... It has honey in its breast and is as shy as a Bengali bride. It won't nag but after exactly five minutes it will call me softly without annoying anyone else. I've swallowed the tablet and informed my life's companion. It won't annoy me any more. $^{\text {xxvi }}$

Here the watch replaces the faithless wife in the novel and fulfils the traditional role of pious and submissive woman, It is more real than most of the other characters in the novel and points to the ideological uneasiness that permeates this sort of fiction. 


\section{The Transaction of Education}

Shankar's overt views on the subject of women, are those of a liberal middle-class Bengali man influenced by the ideals of Gandhi and the Indian National Congress. He acknowledges the very real oppression faced by most women:

If we cannot bring women into the forefront of our society and give them their due responsibility and a major part to play in the community, this country will never progress. In my opinion we are moving backwards because women are regressing. ${ }^{\text {xxvii }}$

However, Shankar, like most men of his class and generation, and indeed like the male protagonists of his novels, finds it hard to conceive of autonomous women. Paradoxically, he ascribes to women much of the blame for their current situation. They have not been able to fulfil the spiritual roles demanded of them in the new nation because they possess all the 'backward' traits of the nation: slavery, self-hatred, lack of self-confidence; they choose financial security over principle and mistake superficial things such as western clothing or proficiency in English with true emancipation. Liberation is impossible until women stop oppressing each other:

Men are definitely primarily responsible for the condition of women but women must bear part of the responsibility too. It is a fact of history in all civilised countries that those who fall behind are always partly responsible for their state; indeed their oppressed condition is one of the prime symptoms of their regression. ${ }^{\text {xxviii }}$ Women are the worst enemies of other unfortunate women...They are most pleased when other women are in trouble... [My father went to jail] ... because my future mother-in-law put pressure on him for more money...She was not willing to compromise even infinitesimally on cash, ornaments or other parts of the dowry.... ${ }^{\text {xix }}$

The new nation does not have enough legitimacy to stop these practices by moral exhortation; men (and women) have to be convinced of the utility of such measures. 
It is difficult to convince people to give away or to sacrifice something [dowry] but they may listen if you say that a sacrifice today will lead to a gain tomorrow. ${ }^{\mathrm{xxx}}$

In Shankar's novels however, the expectations of women are clearer. A woman's interests are congruent with those of her husband and children. In serving them she serves herself. Emancipated and educated (hence westernised) women must maintain this role and representation of themselves to be sympathetic to the reading public. They may go out to work but their prime responsibility is their home and family and they must cut their domestic coat according to their husband's cloth. If a woman acts outside these norms by infidelity, lack of domesticity or piety, she cannot be redeemed unless she repents and recuperates her previous roles.

In the 1950s and 1960s, middle-class women filled these demanding roles. They set up social networks based on their families and localities, and it was through these networks that they reconstituted and supported one another. But with the increasing break-up of the joint family structure, the greater job mobility of both men and women, the rising cost of living and the almost insoluble problems of transport and pollution in Calcutta, these communities have become more difficult to maintain. The contemporary readers of this literature, be they housewife or wage-earner, are increasingly isolated. It is probable that this act of reading constitutes a collective fantasy where the right behaviour and well-played role invariably leads to happiness, and straying from the clearly defined representation of womanhood spells disaster. These women are telling themselves the story of a nation whose central vision is one of surrender to the dominant pre-independence ideology where women and the feminine anchored the nationalist imaginary. Passivity is at the heart of this experience, in the sense that submissiveness to the female ideal produces the balance, harmony and order that are the final goals of each narrative. For example, Abhik Roy, writing in 1998, describes how domesticity was the dominant ideological theme in television commercials in the 1990s where the Indian women is shown as a subservient home-bound wife, happily engaged in domestic chores, whose role is 'crowned' by the advertised product. ${ }^{\text {xxi }}$ The act of reading allows readers to experience the sense of having been reconstituted affectively, if only vicariously.

In this process, reading becomes a transaction. 'Reading for instruction' is a primary justification in a society where modernisation and development have made information a highly valued commodity. Most of these female readers are mothers whose children must pass 
examinations and attend interviews from the ages of four or five to get admission to elite 'English-medium' or 'convent' schools to ensure them a fighting chance of entering the highly coveted professions of medicine, engineering, computing or management. They must not only do extremely well in their school-leaving examinations but also pass difficult competitive tests. Even poorly paid government clerical jobs require English language and general knowledge tests, the latter of which often resemble trivial pursuit games rather than relevant exercises of intelligence. Mothers are usually the after-school tutors of their children; it is not uncommon for children as young as six or seven to require four or five hours of study every evening, to complete their homework and keep up with their studies. The privileging of English language education and the economic imperative of the educated unemployed has thus created a situation where it is mandatory for the middle-class Bengali, traditionally employed in the service sector of the economy, to have a university degree, speak fluent English and possess encyclopaedic general knowledge. The latter qualities represent the capital and passport required for entry into the realm of success depicted in these fictions, the world of plum jobs in foreign companies, banks or the civil service. Women 'learn' English words and expressions that indicate Westernised sophistication from these books as well as historical facts and social and economic data mainly about Europe and America. Shankar is renowned for his 'research' and his novels contain many informative anecdotes, for example how Henry VIII invented the menu and the conduct of whimsical hotel guests in regard to bath water or matching bed linen ${ }^{\text {xxxii }}$. It is not surprising, therefore, that the main response to the question "Why do you read these novels?" was Pore anek kichu jana jay i.e. "One can learn a lot of things by reading (these books)."xxxiii

Reading is thus transformed into an activity where an exchange takes place, where something is acquired. This defines this activity retroactively in developmental terms as goal-directed work and hence culturally desirable replicating the current Bengali middle-class belief that education is closely connected with success and status. A desirable woman is one who, in the public sphere, has to be educated in the English language, but in the domestic world, must retain the values of submissiveness, piety and domesticity that are the hall-marks of the ideal Bengali woman. In stories written from the 1950s onwards, ideal women are highly educated as well as perfect housewives. For example, one such woman is described as not only having a university degree but “ ... also a diploma in interior decoration ... She's a graduate, good-looking, she's certain to get a salary of two hundred and fifty (rupees). ${ }^{\text {xxiv }}$ 
The desirable male protagonist is equally stereotyped. He is modern, personable, tall and either in the possession of a good job or family money. The desirable groom Khagen in 'Ratantikumar' is

personable, well-dressed, obviously wealthy, drives his own car. He was twenty-five or twenty-six years old and working in his father's silver and coal mines. A groom of such beauty, accomplishments, education and money was rare.... ${ }^{\mathrm{xxx}}$

The perfect woman for such a groom has to be a composite of physical, mental and domestic virtues. She must be self-effacing and submissive, an efficient manager of the household, a good mother, educated and accomplished. In 'Ratantikumar' the requirements for such a woman are spelt out in the description of Jayanti. Not only is she an expert cook, but she is beautiful enough not to need make-up and modest to boot:

[Jayanti] has passed her M.A. examination...[She] is going to get a job soon. If you add up Laksmi, Sarasvati and Annapurna and divide by three, you get [Jayanti].”xxxvi

This then is the perfect woman in the new nation: the average of Laksmi, the goddess of wealth, beauty and domestic gifts, Sarasvati, the goddess of music and learning and Annapurna, the goddess of plenty. Both Jayanti and Khagen bring their own capital to this marital bargain. He has all the important attributes of the public sphere, connections and money. She has the essential requirements of the private and domestic sphere, beauty and accomplishment. There is an interesting parallel here with the goddess of the women's wing of the fundamentalist Hindu organisation, the Rashtriya Swayamsevak Sangh (RSS). Their goddess, Ashtabhuja, is a composite of Sarasvati and Lakhsmi but they have replaced Annapurna with Mahakali, who denotes female power and protection. ${ }^{\text {xxxvii }}$

It is important that women subscribe to this psychology of security otherwise the basis for their sexual and social contract will disappear. If a husband cannot provide these objects of security, then the duty and devotion of the wife is enjoined by tradition and religion regardless of the man's character, ability or conduct. In another story, a woman who has been guilty of a pre-marital relationship, redeems herself by becoming a superwoman, caring for a bedridden husband, holding down three jobs as well as keeping the domestic fires burning. Her husband says: 
'[She is] an ideal wife. ... Four years I haven't earned a cent And the whole burden is on her'...Anuradha said, 'What's so difficult about all this? The job is from ten to five. I teach a girl sewing for one hour in the morning and teach music for two hours in the evening'. ${ }^{x x v i i i}$

Women have to resort to nurturance to keep men emotionally in their unique place and also to reify and replicate their own journey to female identity as constructed within the patriarchal culture of the nation. This literature ratifies the inevitability of the institutional structure that defines female needs as identical to those of her husband's and family's and sees fulfilment in their satisfaction. For female readers, this literature is therefore a "kind of sentimental education”, a “culture's ethos when spelt out in a collective text”. xxxix

\section{The Necessity of Success}

Shankar's fiction expresses immense disdain for weak or unwaged men; wives of such men, compelled into the male role of bread-winner, are either overtly independent, promiscuous and disrespectful of their husbands or models of the suffering, patient and ever-dutiful wife. This too continues the national tropes of the bread-winning man and the domestic woman. In another story, a woman who cannot marry because her mother and two younger brothers depend on her earnings, says bitterly:

Harem women seem the happiest to me...What I really want is for a man to hold me always, to look after me, and fulfil my every need and desire so that I never have to leave the harem and go outside... ${ }^{\mathrm{xl}}$

A woman who is more successful than her husband or boy-friend dooms the relationship to failure because their worldly success displaces the man from the centre of the world.:

Tapati was renowned as a good scholar while Somnath was just ordinary. Tapati obtained good marks while Somnath just managed not to fail. Tapati could write and speak beautiful English. Somnath couldn't cope with English at all. ... After this Somnath could not keep pace with his girl-friend ... Tapati put a first-class M.A. degree into her vanity bag with 


\section{DEVLEENA GHOSH}

great ease. Somnath tried and failed to get dozens of jobs in two and a half years but Tapati Ray was a research scholar. Somnath's dream of becoming a poet had withered a long time ago. His employment exchange number was 210017. ${ }^{\text {xli }}$

The theme of male fear of failure and poverty promotes individuation and actualisation of self through acquisition not of inherited wealth or status but the new and individualistic accoutrements of modernity. The men in these writings hunger for specifically economic success, not through the old methods of government service but in the overtly masculine and modern arena of business. The aggressive nature of this world is thoroughly masked under the female characters' extreme economic innocence. Economically passive, the female protagonist lacks options other than marriage or motherhood. Women who buck the system pay with interest for the dissonance they create. In Shankar's novels, the sine qua non of happiness is the material success of the male protagonist. These are basic attributes of his masculinity, without which he cannot control the females in his life. A man of lower status cannot trust his wife to love him for himself alone:

I have neither education nor intelligence, nor the ability to earn money, no virtues at all. How can I tie you to me? That is why I am scared all the time.... xlii

Women must therefore guard themselves against romantic appeal, or 'affect' if there is no 'interest', i.e. economic stability. Happiness is assured if interest and affect meet in a male character. But if those two qualities are distributed between different men, then tragedy is the inevitable consequence. ${ }^{\text {xliii }}$

Much of the success of Shankar's novels is based on the complicity of his readers in accepting unquestioningly the view of themselves that he presents in his works. Women, who are the main consumers of these novels, appear as consumers within the novels and also as objects of consumption who co-operate whole-heartedly in the process. They are the ones who painstakingly guard their husbands' status and throw themselves wholeheartedly into consuming the code: whether enumerating the hierarchy of drinking water or justifying their choice of sari. If a woman is willing to forego status, the man himself repudiates her because he knows that this is what she should want. In Jana Aranya, Tapati wants to marry Somnath but he refuses: 
Tapati asked, “Then I don't have any rights? I can't decide who I love? Can't women love other things about men except jobs?” Somnath answered in a quiet yet sad voice, "If I take what you are offering then no one will forgive me, Tapati. People will think that this unemployed layabout knowingly spoilt the life of an educated, beautiful and innocent girl ... A man who has neither a job nor any earnings is not considered human in this society ... a man is responsible for supporting his wife - this has been a tradition for thousands of years". xliv

This dichotomy in the portrayal of women is emblematic of their paradoxical position in society as commodities and consumers in one.

In the modern Indian nation, sexual inequality is an inescapable fact of Indian life and traditional gender roles, values and expectations still predominate. However, despite the strength of social norms relating to women's roles, within the middle-class that is the subject of Shankar's work, there have been seminal changes in attitudes since independence. Women have entered areas of social life traditionally dominated by men such as higher education, the work force and politics. Urban women's groups have been active since the 1970s in raising the consciousness of women and demarcating their oppression as a major social problem (for example, by the movement against dowry). The ferment over the debate on traditional gender issues is then a theme which should manifest itself in popular literature, especially where authors assert themselves as concerned by injustice or oppression. Shankar seems conscious of this, quoting an extract from an ancient Hindu text in the epigraph of Bittabasana:

There is nothing unachievable for a woman in the three worlds - they can create fire from water and water out of fire. ${ }^{\text {xlv }}$

In spite of these proclamations, Shankar's novels reflect and reinforce traditional social and gender norms while alternatives are presented as non-existent or negative. The family and husband still form the central focus of a woman's life. Higher education and work experience are seen as appropriate insofar as they increase her eligibility for marriage. Such women personify the feminine qualities of the nation, inert, backward-looking and traditional. In the new regime, they sometimes hamper idealistic men from their regimen of duties that have ramifications far removed from the domestic sphere - this masculine work is always of national importance and essential in building the nation. ${ }^{\text {xlvi }}$ 


\section{The Ambiguity of Liberation}

When liberated women appear in these fictions, they have 'westernised' themselves to the point that they have repudiated their spiritual and inward role in the development of the nation. The typical corporate wife's passion in life is the advancement of her husband's career and in presenting the right impression to the world. She is described as taking snuff, smoking and calling her husband by his first name, she would be astounded. "Actually”, says Shankar, "their culture is totally different. It has been imported from England and America, but has come here without being unpacked.”xlvii

The role that the wife of a commercial executive in the corporate world is expected to play is different from traditional expectations only in the details:

In many offices before someone is hired in a high post, the wife of the applicant is interviewed as well. ... We too should receive a salary. The company puts its tired and irritable executives in our hands in the evening after working them to death all day and wringing all the juice out of them. We have to rejuvenate them for work the next day. We do this for the company. (110)

A central theme running through the novels is that the roles of wife and mother are completely satisfying in themselves and leave little room for the achievement of other personal goals. Liberated women characters created by Shankar seldom work out of interest or a sense of vocation. Career women are usually depicted as caricatures; they need supervision and encouragement from charismatic, inspirational and selfless male superiors. Where attempts are made to offer options other than marriage to women, the logic of both language and theme implies that such women cannot be emancipated or fulfilled in current Indian society. This is how a career woman, who has experienced sexual harassment at work describes (western) women's liberation:

Women's liberation was a dirty word in the West. This class of whimsical women refused to take their husbands' names after marriage or be called 
Miss or Mrs, they wore no make-up or even brassieres - all in the name of freedom. [She] definitely did not want this sort of freedom.... ${ }^{\text {xlvii }}$

Ironically, for such women, the solution is to go overseas where they can be truly liberated.

If I become the wife of a teacher, then I shall starve. It's better to stand on one's own feet and escape abroad. As a woman, my slogan is "Liberty, equality, fraternity”. xlix

Shankar's liberated heroines have to 'go west' to be truly emancipated. ${ }^{1}$

Even valid criticism of traditional gender roles are subverted because they are usually articulated by excessively modern and aggressive women, for example an unmarried, cigarette-smoking, motor-bicycle riding teacher:

Physics, chemistry, history, economics, whatever you teach Bengali women, they will eventually spend their lives in the mess of the kitchen, only interested in washing powder, baby food, and talcum powder. When I see my ex-students, it doesn't seem at all credible to me that I ever taught them anthropology....

Since women are accorded the role of guardian of moral values, it is easy in this context to accede to the notion that the nation has lost its moral bearings. In an article on Hindu nationalism, Amrita Basu quotes from a 1991 speech by Sadhvi Rithambara, a female Hindu nationalist:

Things have deteriorated to the point that everything is now bought and sold, minds, bodies, religion, and even the honour of our elders, sisters, mothers and sons ... We cannot auction our nation's honour in the market of party politics. ${ }^{\text {lii }}$

Paola Bachetta has described how ideas, commodities and lifestyle models from other regions and beyond India's borders cause the members of the RSS's women's organisation to 'adjust' their notions of the gender binary and gender complementarity to allow for new forms of agency. ${ }^{\text {liii }}$ But the pronouncements of the leaders of this and similar organisations echo the 
sentiments expressed in Shankar's novels. In 1991, the president of the national women's organisation of the ruling Bharatiya Janata Party said:

“For Indian women, liberation means liberation from atrocities. It doesn't mean that women should be relieved of their duties as wives and mothers. Women should stop demanding their rights all the time and think instead in terms of their responsibilities to the family".

Another office-bearer of the same organisation added: "We want to encourage our members not to think in terms of individual rights but in terms of responsibility to the nation". liv

The parable of the modern nation reaches its culmination in the portrayal of the heroine of Bittabasana ('A Lust for Wealth'), Shankar's most complex novel in this period. Shakuntala is estranged from her first husband, Banabehari, because he is cannot afford to send his terminally sick son overseas for treatment. Masculinity is identified with the ability to access expensive western technologies:

You are a good-for-nothing ... those who can’t make a living are eunuchs ... It's not enough to have physical capabilities - those who can't arrange their children's medical treatment should not be greedy for fatherhood. ${ }^{\text {lv }}$

Banabehari becomes obsessed with acquiring wealth and orchestrates his wife's relationship with a rich businessman who gives him the capital to establish his own business. Shakuntala's decision to leave her first husband, therefore, which might be seen as an act of independence actually requires his active connivance. When she is widowed, her first husband says:
Shakuntala - my wife - is a widow. You might say the term is wrong, it should be ex-wife or previous wife. But mark this: once a wife, always a wife in spite of all the legalities of the land. ${ }^{\text {lvi }}$

Shakuntala becomes a successful entrepreneur by re-enacting the conventional gender roles within the public arena. For example, she rejuvenates her ailing company by cleaning its offices and decorating it with flowers. ${ }^{\text {lvii }}$ She wears the white clothes mandatory for Bengali widows at corporate meetings and functions and observes the appropriate rituals including

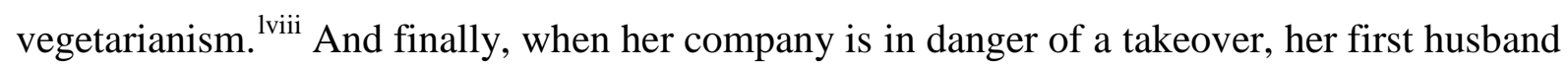
acts as the white knight by acquiring the shares she needs and giving them to her. 


\section{Conclusion: Water Out of Fire}

In the world of writers like Shankar, the path of Nehruvian development is a double sign. It represents the corruption of the licence raj as well as the desirable lifestyle and possessions of the educated elites. The more the nation modernises, the more corrupt and desirable it becomes. All the noble social goals of the Nehru era, education, women's emancipation, progress become transactional - things to be exchanged for wealth, western technology and status. There is no room for integrity here; integrity is possible either in the past or in the West. This topography indicates however the space where right-wing ideologies can flourish; the tropes of the future represented by market liberalisation to assist the new world of commodity, technology and desire coupled with the tropes of the past in the retrieval of traditional ideas of femininity. These fictions tell the story of the 'deferral' of Western modernity in the imaginary of the postcolonial nation. This flawed representation of the modern nation also embodies its tragedy. Nehruvian developmentalism imagined a nation whose trajectory was increasingly mired in corruption and uncertainty. It could not keep its promise to its citizens to provide them with either the necessities of life or the desired symbols of modernity. With the breakdown of the old values that provided safety nets for the less able, entry into this new world and access to its lifestyle is possible only through corruption and betrayal. Ultimately, women cannot make water out of fire.

\footnotetext{
Notes

I would like to thank Mark Berger for his comments and assistance in the preparation of this article.

${ }^{\mathrm{i}} \mathrm{S}$ Khilnani, The Idea of India, London: Penguin Books, 1997, pp 17 - 30.

ii Khilnani, The Idea of India, 1997, pp 76-77.

iii A Kohli, The State and Poverty in India: The Politics of Reform, London: Cambridge University Press, 1987, p 61.

${ }^{i v}$ F R Frankel, India's Political Economy, 1947-1977: The Gradual Revolution, Princeton: Princeton University Press, 1978, pp $246-247$.

${ }^{v}$ Bhabani Sen Gupta, Communism in Indian Politics, New York: Columbia University Press, 1972.

${ }^{v i}$ M T Berger, 'The Rise and Demise of National Development and the Origins of Post-Cold War Capitalism', Millennium: Journal of International Studies, 30(2), 2001 (forthcoming).

vii S. Khilnani, The Idea of India, Chapter Two, pp 61-106.

viii Berger, 'The Rise and Demise of National Development and the Origins of Post-Cold War Capitalism', 2001. S Corbridge and J Harriss, Reinventing India: Liberalization, Hindu Nationalism and Popular Democracy, Cambridge: Polity Press, 2000, 143-172, 192-199. Also see A Vanaik, The Furies of Indian Communalism: Religion, Modernity and Secularization, London: Verso, 1997. T Blom Hansen, The Saffron Wave, Democracy and Hindu Nationalism in Modern India, Princeton: Princeton University Press, 1999.

${ }^{i x}$ N. Menon (ed.), 'Introduction', Gender and Politics in India, Oxford University Press, 1999, p 12.

x S Kaviraj, ‘A Critique of the Passive Revolution', Econnomic and Political Weekly, Annual Number 1988.

${ }^{x i}$ L A West (ed.), Feminist Nationalism, Routledge, London and New York, 1997, p xii.

${ }^{x i i}$ N Yuval-Davis and F. Anthias, Women-Nation-State, Macmillan, London, 1989, p 7

xiii S Walby, "Woman and Nation”, International Journal of Comparative Sociology 33, nos. 1 - 2 (1992): 81.

${ }^{\text {xiv }}$ G Heng “"A Great Way to Fly”: Nationalism, the State and the Varieties of Third-World Feminism', in Feminist Genealogies, Colonial Legacies, Democratic Futures, M. J. Alexander and C T Mohanty (eds.), Routledge, New York 1997, p 31

${ }^{\mathrm{xv}}$ P Chatterjee, The Nation and its Fragments: Colonial and Postcolonial Histories, Oxford University Press, New Delhi, 1993, pp 9, 117.
} 
xvi The mothers of children are the mothers of the nation.

xvii Nirjharini Devi, Desh Saradiya Sankhya, Calcutta, 1950., p 157.

xviii A. McClintock, “'No Longer in a Future Heaven': Gender, Race and Nationlism” in A. McClintock, A. Mufti, \& E. Shohat (eds) Dangerous Liaisons: Gender, Nation and Postcolonial Perspectives, University of Minnesota Press, Minneapolis, 1997.

${ }^{\text {xix }}$ Operations Research Group, 'National Readership Survey (East Zone)', commissioned by the Indian Society of Advertisers Ltd. and the Advertising Agencies Association of India, Calcutta, 1981, pp 16-21 and Appendices 5 and 7

${ }^{x x}$ Mode, 'Report on a Study of Reader Satisfaction of Bengali novels', Calcutta, 11th June, 1982

${ }^{x x i}$ McClintock, “’No Longer in a Future Heaven:”, p 91.

xxii Shankar, Jana Aranya, in the 'trilogy' Svarga-Martya-Patal, Dey’s Publishing, Calcutta, 1981, p 51

xxiii Shankar, Jana Aranya, p 63

${ }^{\text {xxiv }}$ R Bowlby, Just Looking: Consumer Culture in Dreiser, Gissing and Zola, Methuen, New York, 1985.

${ }^{x x v}$ Shankar, Simabaddha, in Svarga-Martya-Patal, Dey’s Publishing, Calcutta, 1981, p12 - 13

xxvi Shankar, Bittabasana, Dey’s Publishing Calcutta, 1983, pp 7 - 40

xxvii All following excerpts are taken from a series of interviews conducted by me with Shankar in Calcutta, in the period $1982-1985$.

xxviii Interview with Shankar, 1982 - 85

xxix Shankar, Gharer Madhye Ghar, Dey’s Publishing, Calcutta, 1990, p 235

${ }^{\mathrm{xxx}}$ Interview with Shankar, Calcutta, January 14, 1984.

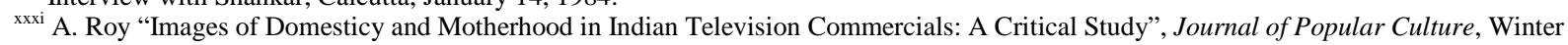
1998, pp $117-134$.

xxxii Shankar, Chowringhee, Dey’s Publishing, Calcutta, 1983, pp 30-40, passim.

xxxiii Phalguni Mukhopadhyay, "Survey of the Reading Habits of Women in Calcutta,” Anandabazar Marketing and Research Cell, Calcutta, 1981, pp 2, 13-14.

xxxiv Jyotirindra Nandi, 'Mirar Dupur' (Mira’s Afternoon), Desh Saradiya Sankhya, Calcutta, 1950, pp 142-143.

xxxv Parasuram, 'Ratantikumar', Desh Saradiya Sankhya, Calcutta, 1952, p 20.

xxxvi Parasuram, 'Ratantikumar', p .23

${ }^{\text {xxvii }}$ P Bacchetta, "Militant Hindu Nationalist Women Reimagine Themselves: Notes on Mechanisms of Expansion/Adjustment”, Journal of Women's History, 10 (4): 125 - 147, 1999 Winter, p 5 of 17.

xxxviii Ramapada Chaudhuri, 'Basuki Basundhara', op. cit., Calcutta, 1950, p 133.

xxxix Clifford Geertz, 'Deep Play’, The Interpretation of Cultures, New York, 1973, p 449.

xl Jyotirindra Nandi, 'Mirar Dupur', p 142 - 143.

xli Shankar, Svarga-Martya-Patal, p 101.

xlii Narendranath Mitra,. 'Sangini', Desh Saradiya Sankhya, Calcutta, 1952, p 207.

xliii R. Bowlby, Just Looking, 1985.

xliv Shankar, Jana Aranya, pp 103, 123-124.

xlv Shankar, Bittabasana, Dey’s Publishing, Calcutta, 1983, epigraph, p 7.

xlvi Shankar, Asha Akankha, Dey’s Publishing, Calcutta, 1981 and Nivedita Research Laboratory, Ananda Publishers, Calcutta, 1966

xlvii Shankar, Simabaddha, p 87.

xlviii Shankar, Nagar Nandini, in Tanaya, Calcutta, 1983, p 103.

xlix Shankar, Simabaddha, p 117.

${ }^{1}$ See for example, Tutul in Seemabaddha and Paromita in Nagar Nandini.

li Shankar, Simanta Sangbad, in Tanaya, Calcutta, 1983, p 24.

${ }^{\text {lii }}$ A. Basu, "Women's Activism and the Vicissitudes of Hindu Nationalism”, Journal of Women's History, Vol. 10 No. 4 (Winter), 1999 , p 113

liii P. Bacchetta, "Militant Hindu Nationalist Women Reimagine Themselves”, p 12.

liv A. Basu, "Women's Activism and the Vicissitudes of Hindu Nationalism", p 117

lv Shankar, Bittabasana, pp 80-92.

lvi Shankar, Bittabasana, p 132.

lvii Shankar, Bittabasana, p 141

lviii Shankar, Bittabasana, pp 149, 171, 185.

\section{References}

P. Bacchetta, "Militant Hindu Nationalist Women Reimagine Themselves: Notes on Mechanisms of Expansion/Adjustment”, Journal of Women’s History, 10 (4): 125 - 147, 1999 Winter

A. Basu, "Women's Activism and the Vicissitudes of Hindu Nationalism", Journal of Women's History, Vol. 10 No. 4 (Winter), 1999

M. T. Berger, 'The Rise and Demise of National Development and the Origins of Post-Cold War Capitalism', Millennium: Journal of International Studies, 30(2), 2001 (forthcoming).

R. Bowlby, Just Looking: Consumer Culture in Dreiser, Gissing and Zola, Methuen, New York, 1985.

P. Chatterjee, The Nation and its Fragments: Colonial and Postcolonial Histories, Oxford University Press, New Delhi, 1993

A. Chattopadhyay, 'Shankar: Best Sellerer Asha Akankha', Paribartan, Calcutta, December 1, 1982

R. Chaudhuri, 'Basuki Basundhara', Desh Saradiya Sankhya, Calcutta, 1950

S. Corbridge \& J. Hariss, Reinventing Indian: Liberalization, Hindu Nationalism and Popular Democracy, Polity Press, Cambridge, 2000

S. Das, 'Desh: Panchas Bachharer Itihas’, Desh, Subarnajayanti Sankhya, Calcutta, 1983

Nirjharini Devi, 'Santan Janani Jatir Janani’, Desh Saradiya Sankhya, Calcutta, 1950

F. R. Frankel, India’s Political Economy, 1947 - 1977: The Gradual Revolution Princeton University Press, Princeton, 1978 


\section{FIRE OUT OF WATER}

C. Geertz, 'Deep Play’, The Interpretation of Cultures, Hutchinson, London, 1975

T. B. Hansen, The Saffron Wave,: Democracy and Hindu Nationalism in Modern India, Princeton University Press, Princeton, 1999

G. Heng “"A Great Way to Fly”: Nationalism, the State and the Varieties of Third-World Feminism', in Feminist Genealogies, Colonial Legacies, Democratic Futures, M. J. Alexander and C. T. Mohanty (eds.), Routledge, New York 1997

S. Kaviraj, 'A Critique of the Passive Revolution', Econnomic and Political Weekly, Annual Number 1988

S. Khilnani, The Idea of India, Penguin Books, London and New York, 1997

A. Kohli, The State and Poverty in India: The Poitics of Reform, Cambridge Universtiy Press, London, 1987

A. McClintock, “'No Longer in a Future Heaven': Gender, Race and Nationlism” in A. McClintock, A. Mufti, \&

E. Shohat (eds) Dangerous Liaisons: Gender, Nation and Postcolonial Perspectives, University of Minnesota Press, Minneapolis, 1997.

N. Menon (ed.), 'Introduction', Gender and Politics in India, Oxford University Press, 1999

Mode, 'Report on a Study of Reader Satisfaction of Bengali novels', Calcutta, 11th June, 1982, 1992

P. Mukhopadhyay, "Survey of the Reading Habits of Women in Calcutta," Anandabazar Marketing and Research Cell, Calcutta, 1981, 1987

J. Nandi, 'Mirar Dupur' (Mira’s Afternoon), Desh Saradiya Sankhya, Calcutta, 1950

Operations Research Group, 'National Readership Survey (East Zone)', commissioned by the Indian Society of Advertisers Ltd. and the Advertising Agencies Association of India, Calcutta, 1981

Parasuram, 'Ratantikumar', Desh Saradiya Sankhya, Calcutta, 1952

A. Roy, "Images of Domesticy and Motherhood in Indian Television Commercials: A Critical Study”, Journal of Popular Culture, Winter 1998, pp. 117 - 134.

P. K. Sanyal, 'Bharbahi', Desh Saradiya Sankhya, Calcutta, 1950

B. Sen Gupta, Communism in Indian Politics, New York, Columbia University Press, 1972

Shankar, Asa Akankha in Svarga-Martya-Patal, Dey’s Publishing, Calcutta, 1981

Bittabasana, Dey’s Publishing Calcutta, 1983

Chowringhee, Dey’s Publishing, Calcutta, 1983.

Gharer Madhye Ghar, Dey’s Publishing, Calcutta, 1990

Jana Aranya, in Svarga-Martya-Patal, Dey’s Publishing, Calcutta, 1981

- Nagar Nandini, in Tanaya, Calcutta, 1983

Nivedita Research Laboratory, Ananda Publishers, Calcutta, 1966

Simabaddha, in Svarga-Martya-Patal, Dey’s Publishing, Calcutta, 1981,

Sunday, December 5, 1983, p. 26.

A. Vanaik, The Furies of Indian Communalism: Religion, Modernity and Secularization, Verso, London, 1997

S. Walby, "Woman and Nation”, International Journal of Comparative Sociology 33, nos. 1 - 2 (1992): 81.

L. A. West (ed.), Feminist Nationalism, Routledge, London and New York, 1997

N. Yuval-Davis \& F. Anthias, Women-Nation-State, St. Martin’s Press, New York. 